INTERNATIONAL HIGHER EDUCATION, No. 67, Spring, 2012 Pages 9-11

The European Medieval Universities, from the Past and Today

\author{
MiRi RubiN
}

Miri Rubin is professor of medieval and early modern history at Queen Mary, University of London. E-mail: m.e.rubin@qmul.ac.uk. (A different version of this article appears in Times Higher Education.)

As a historian of the Middle Ages, I am frequently asked about the links between universities then and now. Given the momentous changes affecting modern-day institutions of higher education and the lives of so many people-students, parents, teachers, and employers-such questions have become more frequent and more urgent. Given a great deal is different between the medieval universities and our own diverse global array of institutions, this makes comparisons difficult. None the less, an assessment of the role of medieval universities reveals some telling affinities that may hold lessons for today's turbulent times.

\title{
Church AND STATE
}

When universities emerged between 1150 and 1200 in Italy, France, and England, they responded to the needs of the main institutions of governance-the Church and dynastic kingdoms. Both systems' institutions required bureaucrats, trained in the procedures of government and its language, Latin. Latin still depended on the conventions developed in the classical antiquity, and these were transmitted 
through the study of the liberal arts of rhetoric, logic, and grammar. Jobs for graduates-bachelors of arts—ranged from the drafting of letters, treaties, and keeping of financial records.

Church and states managed justice, this also required legal experts: men trained beyond the liberal arts to higher degrees in law, just as they progress in the United States today—from the bachelor of arts to further studies in medicine and law. To support this all-important training-popes, kings, and emperors were willing to allow groups of students and teachers to come together in Bologna, Paris, Oxford, and Cambridge. They exempted scholars from taxes and allowed students and scholars to be self-governing. The papacy licensed universities to award degrees that were recognized throughout Europe. The bachelor of arts became the gold standard for a certain type of literacy and administrative capacity throughout the Christian world.

\section{Medieval Realities}

Yet, potential employers who stood to benefit most from well-trained personnel did not provide comprehensive funding for students. They exempted universities from some dues-just as much of today's educational sector enjoys charitable status in many places—-thus, each student needed to seek support. For some students this was easy. Clever monks were supported by their religious houses; bishops sponsored men on the condition that the scholars worked for them after graduation; lords of manors supported talented local boys who would return as household chaplains, secretaries, or parish priests. Most students had to create packages of funding, based on patronage, family support, and paid work. Accordingly, dropout rates in medieval universities were very high; the lists of 
matriculated students were always much longer than of those who graduated with the bachelor of arts. For students who relied on the whims of benefactors, any breakdown in the relationship could force them to drop out. Given the more precarious supports for university study, students are less likely to complete their courses. If students are required to beg and borrow support, they may well fall out of the system-wasting the time and the funds already invested in them.

Another interesting point arises from the high-dropout rate at medieval universities. Those who left before graduating were still able to use the skills acquired to secure employment. The skills were highly transferable and in such short supply, that even people who had studied for only a year or two had an advantage. They could become one of thousands of teachers, tutors, scribes, and recorders that medieval society required-modest medieval equivalents to Steve Jobs and Mark Zuckerberg.

Finance of universities was closely linked to student enrollments during the Middle Ages. Outside certain areas of present-day Germany and Italy, most landed and titled people educated their sons at home. Their heirs did not need to follow a profession taught and accredited by the universities. Nor were universities the sole recruiters and trainers of bright, ambitious men. Whole areas of activity were not taught in universities. There were guild apprenticeships for surgeons, merchants, and notaries; the Inns of Court for aspiring lawyers; Chancery training for civil servants; workshops for artists; and military training at royal and aristocratic courts and within fighting units.

Finally, regarding creativity, the futility of some aspects of medieval university learning, especially the system known as scholasticism, has long been the subject of satire-just as it was lampooned in the Middle Ages. Scholasticism 
was a method of training through dialectical probing, applied to questions ranging from medical to theological studies. Dialectical questioning for and against a preposition was familiar to all educated people and enabled some sharp and radical thinking. The philosopher Peter Abelard (1079-1142) used it in Paris (albeit before the university was founded) to question the existence of God; the theologian John Wycliffe (ca. 1330-1384) in Oxford, to question the nature of the sacraments and the relationships between church and state; and the biblical scholar and theologian Martin Luther (1483-1546) at Wittenberg University, to assail a 1,000-year-old system of Christian belief and practice, changing it forever. Far from being stale and predictable, medieval universities produced not only civil servants and ecclesiastical bureaucrats but also radical thinkers, whose work had real impact and who-despite their challenging critiques-died in their beds, not in prison cells.

\section{CONTEMPORARY LESSONS}

With millions aspiring to university education in Europe, the United States, India, and China-we face the challenge of making universities an effective training ground, while also a center for creativity and boldness. In the medieval universities young men were set apart for a period of intensive intellectual and social interaction, away from home, among peers, and in the presence of inspiring teachers. The skills imparted were highly transferable because they were generic: the ability to analyze texts, argue a case, examine problems from all points of view, and interrogate questions in order to reach solutions. Their liberal arts curriculum was already hundreds of years old, and it combined instruction in verbal dexterity with training in numbers and proportions. Like graduates 
today, some in the Middle Ages expected to serve and manage in their own countries, while others aspired to travel beyond on missions or for further study-armed with highly transferable skills. They studied all that was essential for the critical understanding of systems, for managing complex entities, for observing the world and for the forging of solutions to ever-emergent challenges.

Such educated men expected to interact throughout their careers with people accomplished in other skills and trained otherwise: surgeons, notaries, architects, painters, merchants, soldiers, and map makers. Guilds, courts large and small, Inns of Court, and family workshops all trained people to crafts that could lead to financial reward and renown. A combination of bookish learning and guild training was necessary to produce such marvels as the 13th-century remaking of Westminster Abbey or the poetry of Geoffrey Chaucer, a century later.

\section{LESSONS FOR TODAY}

Thinking about medieval universities might provide some beneficial lessons. Perhaps we should not burden students with having to seek finance during this crucial period of training. Such burdens lead to suboptimal performance and the wasteful abandonment of precious university places. Since their skills are a common good, everything should be devised and encouraged-comfortable student loans, scholarships, state support, and charitable endowment-to keep universities free at the point of access.

Another lesson is that the universities are not alone in fostering excellence. While the skills of high-level critical thinking and communication are essential to all forms of governance, other forms of reasoning and practice also deserve 
support and remuneration—design, craft, engineering, and more.

Transferability of skills should be central to higher education. As students are challenged by the rich heritage of human understanding-literature, languages, arts, social theories, sciences, and philosophy-they develop out of those specialized intricacies the ability to analyze and build, correct, and complement. What is worth studying should not be decreed by crude utilitarianism. For training the mind, we need both Latin and mathematics.

At a time of flux in modern higher education, policymakers, presidents, and academics should not overlook the past when mapping out the future. 